\title{
Geological study of carbonate band in Upper Bhuban Formation, Mizoram, India
}

\author{
C. Lalmuankimi ${ }^{1}$, Shiva Kumar ${ }^{2}$, R.P. Tiwari $^{2}$ \\ ${ }^{1}$ Department of Geology, Government Zirtiri Residential Science college, Aizawl 796007, Mizoram \\ ${ }^{2}$ Department of Geology, Mizoram University, Aizawl 796004, Mizoram, India \\ Corresponding author: muankimi@gmail.com
}

\begin{abstract}
The main carbonate band in Upper Bhuban unit in Bhuban Formation of Surma Group in Mizoram is exposed in an N-S trending hill range about $5 \mathrm{~km}$ northeast of Muthi village in Aizawl district. Representative samples from the study area were prepared for rock thin sections and were also analyzed for their major oxides by Xray fluorescence to find out the mineral content and dolomitisation process. The limestone, which constitutes angular grains of calcite detritally accumulated with shell fragments and organic structures. The shell fragment belongs to echinoids, bryozoans and oysters in a sparitic matrix. Several foraminifera are also found in rock thin sections and it is the first time Index microfossil has been identified in Carbonate band of Upper Bhuban formation. Calcite is colourless under plane Polarized light showing distinct twinkling and low relief. Between cross-nicols, it shows high order interference colour red, blue. It exhibits perfect rhombus grains having two distinct cleavages. Organic shell structure is observed and is wholly made up of calcite. The non-carbonate constituents of the Upper Bhuban carbonate rocks comprise of quartz, microcline, biotite, phosphorite, glauconite with augite and also an opaque mineral of limonite in considerable amount. Quartz is the most abundant non-carbonate constituent mineral in the Upper Bhuban carbonate band. It is characterized by low relief between cross-nicols. It shows first order grey colour, wavy extinction and exhibits angular to sub-angular grained. The petrological studies suggest that the limestone was formed by accumulation of shell fragments with inclusion of detritus sediments. The concentration of $\mathrm{CaO}$ ranges from 30.812 to $43.48 \%$ and the ratio of $\mathrm{Mg} / \mathrm{Ca}$ is low varying from 0.03 to 0.07 indicating that the process of dolomitization is not significant.
\end{abstract}

Keywords: Petrography, $\mathrm{Mg} / \mathrm{Ca}$ ratio, exploration of carbonate band in Upper Bhuban Formation, Aizawl District, Mizoram.

\section{INTRODUCTION}

No systematic work has been carried out based on petrological analysis in the carbonate band in Upper Bhuban unit in Bhuban Formation of Surma Group of Mizoram. This is the first and newly reported result from this area. However, an assemblage of planktic and benthic foramnifera in Carbonate band from the Upper Bhuban unit of Bhuban Formation, Mizoram is documented (Lalmuankimi et al., 2010). It is in this background that an exploration of carbonate band exposed at Sailungvar $\mathrm{Hmun}$ at Muthi Village in the Aizawl district of Mizoram has been selected (Figure 1). The aim of the present work is to carry out mineral content and prevalent of dolomitisation process in carbonate band occurring as lensoid body in Upper Bhuban formation of Surma Group.

\section{MATerials AND Methods}

The present study in carbonate band in the Upper Bhuban Formation in Aizawl District comprises of field work and laboratory work. The carbonate band is grey in colour, it is hard and appears to be composed of shell fragments. A representative sample of limestones was collected systematically from the area under study. The samples collected in the field were subjected to laboratory analyses. Several rock thin sections were prepared 


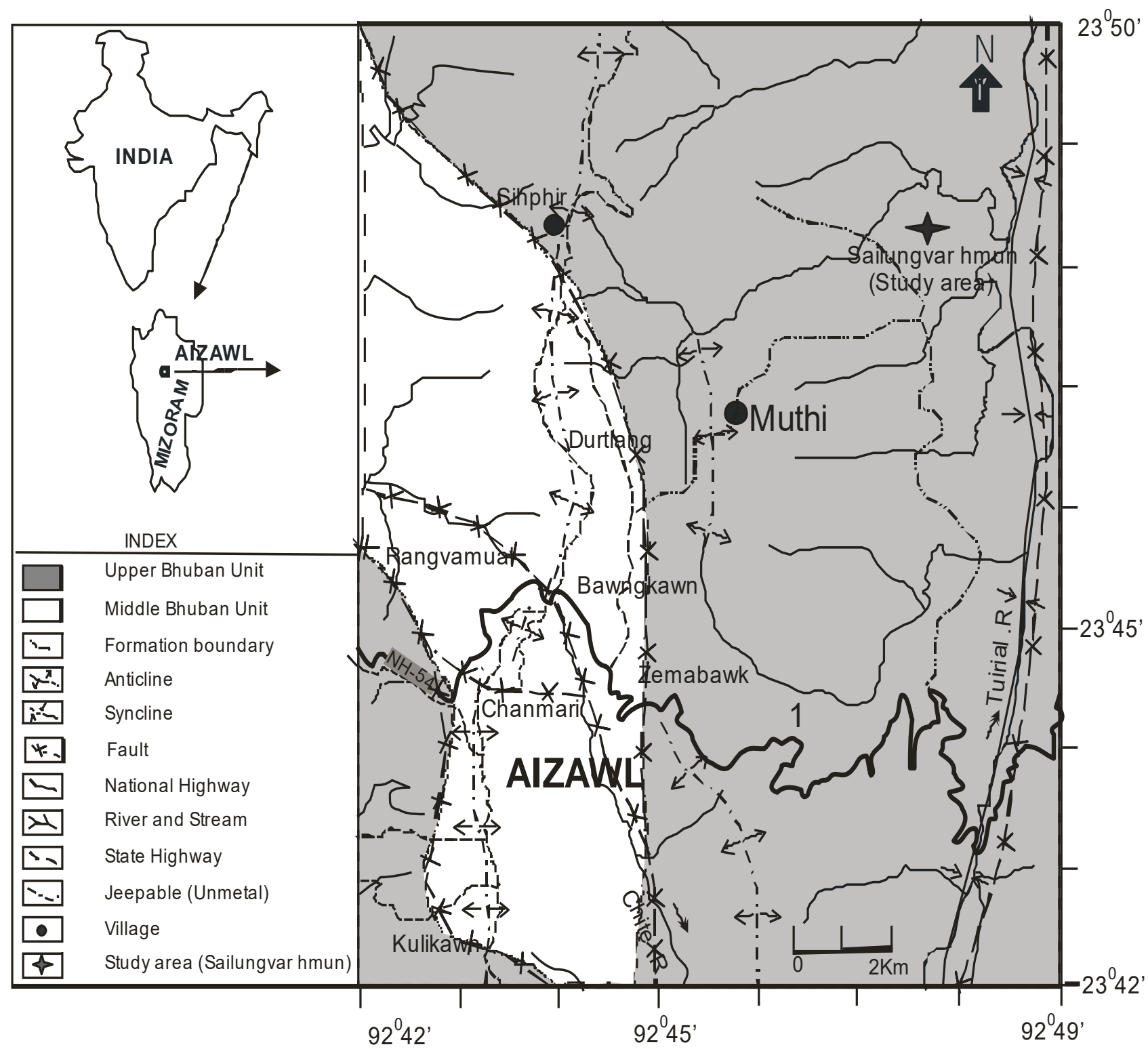

Figure 1: Location map of the study area.

in order to study petrography. Thin sections were studied on Leica DM EP petrological microscope. Microfossils and skeletal fragments were studied on high magnification Leica zoom Microscope. Folk's scheme of classification of limestone (1959) is used for petrographic description of Upper Bhuban limestone. Selected rock samples were powdered and processed to determine major oxides. It was performed on X-ray fluorescence (XRF). Among the major oxides $\mathrm{CaO}$ is taken as a common factor in the chemical variation. $\mathrm{Ca} / \mathrm{Mg}$ ratios are used to determine whether the carbonate band is dolomitised.

\section{RESULTS}

The colour of Muthi limestone is variable in hand specimen. The colour ranges from yellow brown to dark brown and brownish grey. The band occurs as a lensoid body with a maximum thickness of $20.1 \mathrm{~m}$ and a maximum length of nearly $80 \mathrm{~m}$. In the field, this unit can be identified as calcareous sandstone. It consists of decimeter-thick calcareous sandstone alternating with several centimetre-thick mud layers. It occurs between $82.5 \mathrm{~m}$ splintery shale horizon (below) and $5 \mathrm{~m}$ thick loose buff sandstone (above). The carbonate band is hard and appears to be composed of shell fragments. The shell fragments usually comprise bivalves and echinoids. However, thin sections have yielded foraminifers, echinoids, bivalves, bryozoans and non-carbonate constituents were observed in rock thin sections.

Calcite: Calcite records are present in all the rock thin sections and constitute variable proportion with reference to quartz and feldspars in the rock composition. It is colourless under plane Polarized light showing distinct 


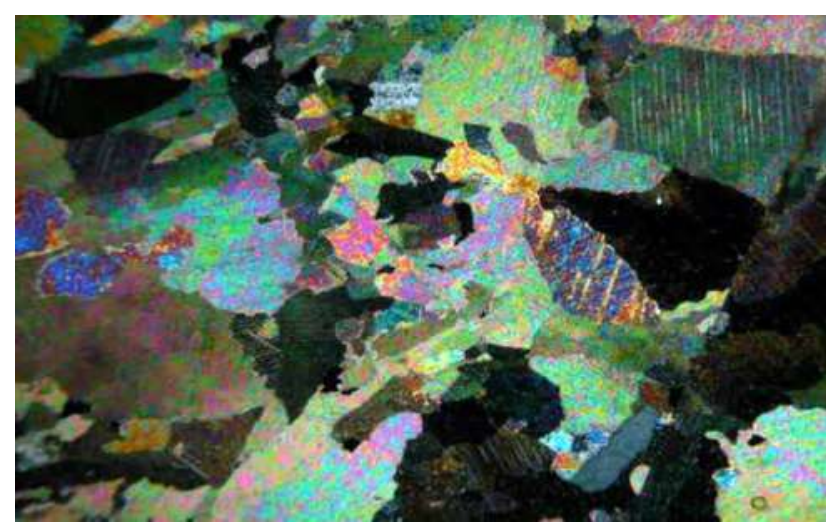

Figure 2: Calcite showing high order interference colour.

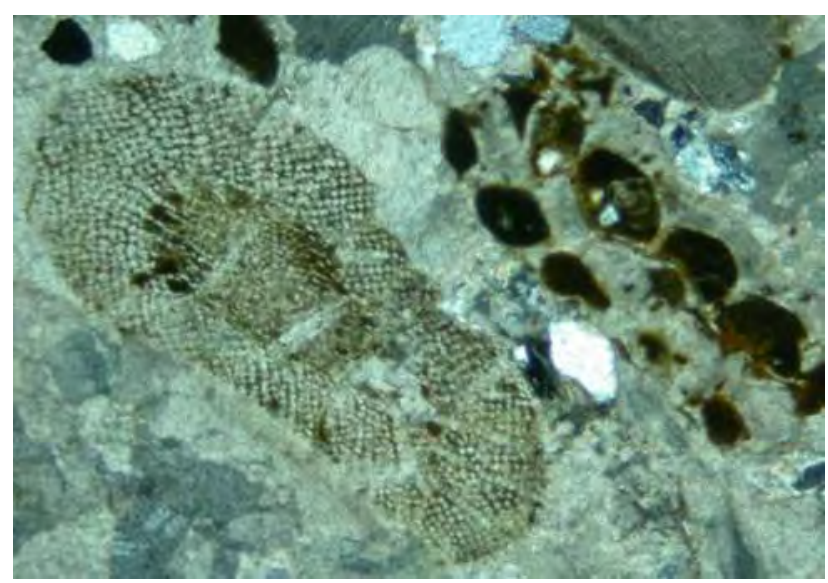

Figure 4: Shell fragments in sparitic matrix.

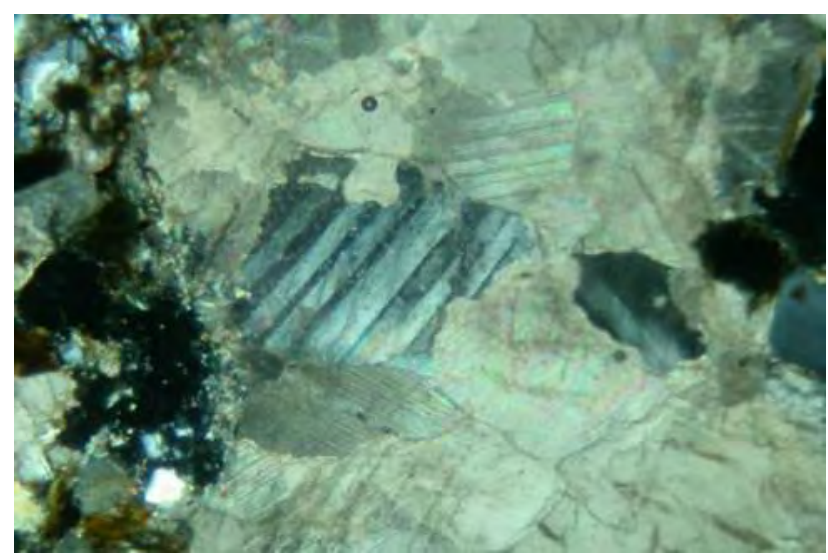

Figure 6: Albite showing lamellar twinning.

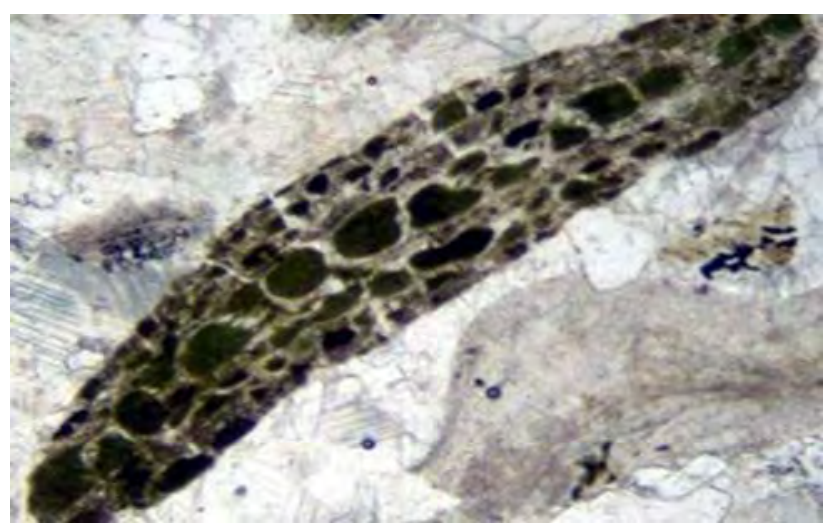

Figure 3: Index-micro fossil.

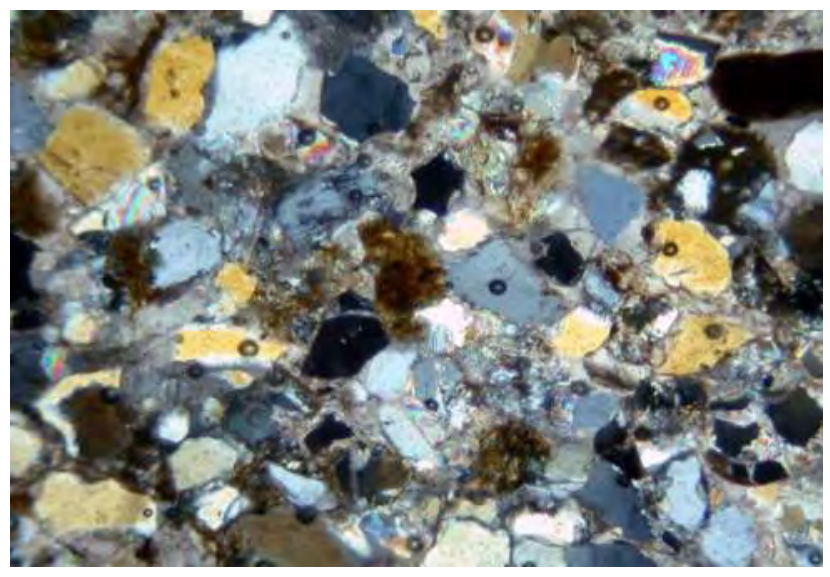

Figure 5: Quartz showing angular to sub-angular grained.

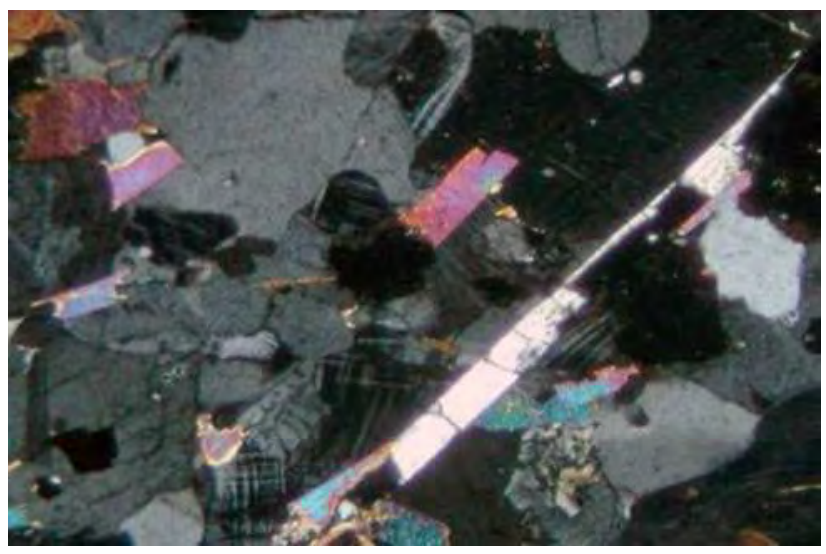

Figure 7: Microcline showing cross-hatched twinning.

Table 1: Concentration (\%) of $\mathrm{CaO}, \mathrm{CaCO}_{3}$ and ratios of $\mathrm{Ca} / \mathrm{Mg}$.

\begin{tabular}{|c|c|c|c|c|c|c|c|c|c|c|}
\hline $\begin{array}{l}\text { Oxide/ } \\
\text { Sample }\end{array}$ & $\begin{array}{l}\text { K-MT- } \\
1\end{array}$ & \begin{tabular}{|c} 
MK-MT \\
2
\end{tabular} & \begin{tabular}{|c} 
MK-MT- \\
$\mathbf{3}$
\end{tabular} & \begin{tabular}{|c} 
MK-MT- \\
4
\end{tabular} & \begin{tabular}{|c} 
MK-MT- \\
5
\end{tabular} & \begin{tabular}{|c} 
MK-MT- \\
6
\end{tabular} & $\begin{array}{c}\text { MK-MT- } \\
7\end{array}$ & \begin{tabular}{|c} 
MK-MT- \\
8
\end{tabular} & \begin{tabular}{|c} 
MK-MT \\
9
\end{tabular} & $\begin{array}{c}\text { MK-MT } \\
10\end{array}$ \\
\hline & & & & & & & 43.48 & 34.69 & 33.58 & 0.77 \\
\hline & & & & & & & & & 2 & 41 \\
\hline $\mathrm{Ca}$ & 05 & 0.06 & 06 & 0.05 & 0.06 & 0.06 & 0.03 & 0.04 & 0.03 & 0.07 \\
\hline
\end{tabular}

MK-MT is sample number. 
twinkling and low relief. Between cross-nicols, it shows high order interference colour red blue etc. of III\& IV order (Figure 2). It usually exhibits perfect rhombus grains having two distinct cleavages. Further these calcite grains are also occurring within the shell or within the worm tube showing non-clastic texture. Fine to very fine interlocked calcite grains, are found in the remaining part of the rock. In addition, medium grained calcites are also found in association with quartz, and feldspar mostly along with the matrix of argillaceous composition. The angularity in calcite grains is also observed. Sometimes organic shell structure is observed consisted and wholly made up of calcite.

Fossils: The Muthi limestone is poor in mega-biota. Shell fragments, foraminifers are observed and index microfossil was also identified from the thin section (Figure 3). The shell fragments are of echinoids, bryozoans and several oysters in a sparitic matrix (Figure 4). Several foraminiferal tests were found occurring in random thin sections. The bryozoans exhibit bifurcation or splits like a tree trunk giving rise to new branches and the interstitial cement and overgrowths on the remaining tests are noticed. The individual grains of echinoids appeared in various shapes such as circles, squares, rectangles and arranged in multi-layered shell pattern exhibiting prismatic texture.

Quartz: Quartz is another abundant constituent of Muthi limestone. It is characterized by low relief between cross-nicols it shows first order grey colour and wavy extinction. It is showing angular to sub-angular grains (Figure 5).

Albite: In polarized light, it is colourless, two sets of cleavage and low relief. It is showing first order grey colour and lamellar twinning between cross-nicols (Figure 6).

Microcline: Microcline grains are noticed with colourless, low relief and two sets of cleavages at right angles to each other under polarized light. Further, between crossed nicols it exhibits I order grey colour and crosshatched twinning (Figure 7).

Muscovite, Biotite and also opaque minerals of limonite are also observed in considerable amount. The authigenic minerals like glauconite and phosphorite are present in small quantity. Glouconite is potassium mineral and green color with very low weathering resistance.

The concentration of $\mathrm{CaO}$ in percentage varies from 30.812 to $43.48 \%$ having mean value of $37.78 \%$ and $\mathrm{CaCO}_{3}$ ranges from 41.41 to 76.16 . The ratio of $\mathrm{Mg} / \mathrm{Ca}$ is low varying from 0.03 to $0.07 . \mathrm{CaO}, \mathrm{CaCO}_{3}$ and ratios of $\mathrm{Ca} / \mathrm{Mg}$ are given in Table 1.

\section{DISCUSSION}

The Upper Bhuban limestone is mainly composed of skeletal fragments, foraminifers, terrigenous sediments and authigenic minerals in small amount. Calcite was observed as sparitic matrix and angular to sub-angular grained. Many shell fragments are completely leached out and the voids are filled up by sparry calcite. Crystals deposited within veins, pore spaces or fissures are called sparite (Folk, 1959). An assemblage of both benthic forms and planktic foraminifers indicated that near shore environment and can tolerate influx of clastic material. Fragments of carbonate shell-bearing organisms, especially the oysters are common in a sparitic matrix and shows microborings. These features and authigenic indicate mechanical reworking of shells by waves and currents, slow rate of deposition. Presence of planktic foraminifers indicates influence of open sea condition. It seems that the fossiliferous carbonate band of the Upper Bhuban unit was deposited in the near shore environment with high energy conditions under influence of open sea conditions (Lalmuankimi et al., 2010). The authigenic minerals are marine origin and material reworked from pre-existing strata or transported from outside the depositional basin. The petrological studied reveal that limestone in Upper Bhuban formation is unsorted biosparite and it was formed by accumulations of shell fragments and terrigenous sediments.

The simplest criterion for dolomitized rocks is the relative percentage of calcite to dolomite (Greensmith et al., 1989). The ratio of $\mathrm{Mg} / \mathrm{Ca}$ is low varying from 0.03 to 0.07 in the Upper Bhuban limestone. These low values indicate that the carbonate band is not dolomitized because dolomitization would necessarily cause a marked increase in the $\mathrm{Ca} / \mathrm{Mg}$ ratio of the limestones (Kaufman et al., 1992). The character of $\mathrm{Mg} / \mathrm{Ca}$ ratios positively reveals that the process of dolomitisation is not significant in the Upper Bhuban Carbonate band in Bhuban unit of Surma Group in Aizawl District of Mizoram.

\section{ACKNOWLEDGEMENT}

I thank Dr. V.P. Dimri and Dr. Mrinal Kanti Sen, Director National Geophysical Research Institute, Hyderabad, for granting me permission to carry out analytical works at his prestigious Institute. I must also acknowledge Dr. J. Malsawma, Asst. Professor, Department of Geology, Mizoram University, who often accompanied me in my field visits. I am also thankful to the ministry of Social Justice and Empowerment, Ministry of Tribal Affairs and UGC, India for awarding me Rajiv Gandhi National Fellowship for ST candidates and for providing me financial help and DST-FIST (NER).

\section{REFERENCES}

Lalmuankimi, C., Tiwari, R.P., Jauhri, A.K., Ralte, V.Z. (2010). Foraminifera from the Bhuban Formation of Mizoram. Journal of the Palaeontological Society of India, 55(1): 71-75.

Greensmith, J.T. (1991). Petrology of the Sedimentary Rocks $7^{\text {th }}$ Edition. New Delhi: CBCS Book Publishers, 
pp. 142-148.

Kaufman, A. J., Hayes, J. M., Knoll, A. H., Germs, G. J. B. (1991). Isotopic compositions of carbonates and organic carbon from Upper Proterozoic successions in Namibia: Stratigraphic variation and the effects of diagenesis and metamorphism. Precambrian Rex, 49, 30I-327.

Kaufman, A.J., Knoll, A.H., Awramik, S.M. (1992). Biostratigraphic and chemostratigraphic correlation of Neoproterozoic sedimentary successions: Upper Tindir Group northwestern Canada, as a test case. Geology, 20(2), 181-185.
Sedat, T., Hukmu, O., Arif, D. (2009). Geochemistry of the limestone of Mortas Formation and related Terra Rossa, Seydisebir, Konya, Turkey. Geochemistry International, 47(1): 67-93.

Sengupta, S.M. (1996). Introduction Sedimentology. New Delhi: Oxford \& IBH Publishing Co. Pvt. Ltd, pp. 70-76. 